\title{
SELENIUM STATUS OF SHEEP AND THEIR LAMBS IN THE NORTHERN SERBIAN PROVINCE OF VOJVODINA
}

PEŠUT OLIVERA, JOVANOVIĆ BI, GVOZDIĆ D and STOJIĆ V

Faculty of Veterinary Medicine, Belgrade

(Received 12. July 2004)

The blood plasma concentrations of selenium and plasma and whole blood GSH-Px activities were determined in 30 sheep on three farms $(A=K a c ́, B=E c ̌ k a$ and $C=$ Čoka) in marginally deficient areas of Vojvodina. Selenium concentrations in feedstuffs from the territories surrounding the studied farms were lower than $0.10 \mathrm{ppm}$ in more than $90 \%$ of the samples. Plasma selenium concentrations in sheep from farms $A, B$ and $C$ were $83.44 \pm 19.09 \mu \mathrm{g} / \mathrm{L} ; 183.90 \pm 37.10 \mu \mathrm{g} / \mathrm{L}$ and $82.14 \pm 25.09 \mu \mathrm{g} / \mathrm{L}$ respectively. Plasma GSH-Px activity was the lowest on farm $B(0.70 \pm 0.37 \mu \mathrm{kat} / \mathrm{L})$, nonsignificantly higher on farm $A(0.81$ $\pm 0.40 \mu \mathrm{kat} / L)$ and highest on farm $C(1.66 \pm 0.88 \mu \mathrm{kat} / \mathrm{L})$. Mean whole blood GSH-Px activities ranged between $194.38 \mu \mathrm{kat} / L$ (farm C) and $236.51 \mu \mathrm{kat} / \mathrm{L}$ (farm B).

On farm $A$ the blood plasma concentrations of selenium and plasma and whole blood GSH-Px activities were determined also in suckling lambs in relation to their mothers. Plasma selenium content in lambs (50.58 $\pm 10.06 \mu \mathrm{g} / \mathrm{L})$ was lower than in adult sheep at the same location. Both plasma (0.81 $\pm 0.40 \mu \mathrm{kat} / \mathrm{L})$ and whole blood (424.21 \pm $117.19 \mu \mathrm{kat} / \mathrm{L}$ ) GSH-Px activities were significantly higher in lambs compared to their dams.

Key words: selenium, glutathione peroxidase, sheep, lambs

\section{INTRODUCTION}

After its discovery in 1817 , selenium was for a long time known only for its highly toxic properties. Later on selenium was established as a nutritionally essential microelement, being a component of glutathione peroxidase (GSH-Px) (Rotruck et al., 1973). Glutathione peroxidase is a selenoenzyme that plays a major role in the protection of cells against oxidative damage by endogenous peroxides. Peroxides can damage cell membranes leading to degeneration and necrosis.

The principal methods for the assessment of selenium status include determination of its concentration and measurement of GSH-Px activities in tissues, as well as the occurrence and intensity of Se responsive diseases in animals. A close correlation between the activity of GSH-Px and the selenium 
status has been repeatedly demonstrated (Erskine et al., 1987; Harpin et al., 2000).

The activity of erythrocyte GSH-Px defines the long-standing selenium status because synthesis of the enzyme occurs only during erythropoesis, as mature erythrocytes do not have the organelles needed for protein synthesis (Osame et al., 1990). Consequently, determination of plasma selenium level is preferable when one wishes to estimate current selenium status. The variations of plasma and serum selenium content during the physiological steady state was explained on the basis of rapid hepatic uptake of selenium and its subsequent reappearance in the circulation in a protein bound form followed by further metabolism and excretion of the element (Hoshino et al., 1989).

In young sheep, two selenium-responsive conditions are recognized; one a myopathy of lambs, white muscle disease (WMD), the other a syndrome of lowered productivity ranging in severity from poor wool production to a clinical condition known as selenium responsive unthriftiness (SRU) consisting of poor growth, infertility and increased fetal mortality rates (Andrews et al., 1968). Although these conditions have been clearly associated with selenium deficient areas, they have been difficult to reproduce under experimental conditions (Stowe and Herdt, 1992).

The purpose of this study was to investigate the selenium status in different flocks of sheep feeding on locally grown feedstuffs at three localities in the Vojvodina region.

\section{MATERIAL AND METHODS}

\section{Experimental animals}

The study was conducted at three farms situated near the towns of Kać (Farm A), Ečka (Farm B) and Čoka (farm C) in the northern Serbian province of Vojvodina. Three groups of 10 sheep each (Wirtenberg $\times$ Cigaja crossbreds), were formed on each farm on the basis of a common age range (3-4 years) and sex (female), multiparity and feeding on locally grown forage and grain. Blood samples were also collected from suckling lambs on farm $A$.

\section{Blood and feedstuff samples}

After puncture of $v$. iugularis blood samples were collected in heparinized test tubes. To obtain plasma part each sample was centrifuged at $1500 \mathrm{xg}$ for 15 minutes. Each sample was divided into two: fresh whole blood and plasma were utilized immediately for determination of selenium dependent GSH-Px activity, and the remaining plasma was frozen at $-20^{\circ} \mathrm{C}$ for subsequent Se analysis.

Samples of feedstuffs for determination of Se content were collected randomly from the territory approximately $15 \mathrm{~km}$ around each farm.

\section{Selenium determination}

Selenium concentration was determined using hydride generation atomic absorption spectrophotometry (Welby et al., 1987). Glutathione peroxidase (GSH- 
Px - EC. 1.11.1.9) activity was analyzed spectophotometrically by a coupled test (Günzler et al., 1974) using a concentration of tertiary butyl hydroperoxide (TBH) below 2,32 mM in order to measure only the activity of selenium dependent GSHPx (Sankari, 1985).

\section{Statistical analysis}

The significance of differences between groups was calculated using Student's t-test where $\mathrm{p}<0.05$ was considered statistically significant. (SPSS Inc. Sigma Plot for Windows v. 8.0).

\section{RESULTS}

Selenium concentrations in feedstuffs originating from locations surrounding farm $A(n=7)$, farm $B(n=10)$ and farm $C(n=4)$ were $25 \mu \mathrm{g} / \mathrm{kg}$, above $50 \mu \mathrm{g} / \mathrm{kg}$ and ranging from 25 to $50 \mu \mathrm{g} / \mathrm{kg}$ respectively.

Plasma selenium content and GSH-Px activities in blood plasma and whole blood of adult sheep from farms A, B and C are presented in Figure 1.

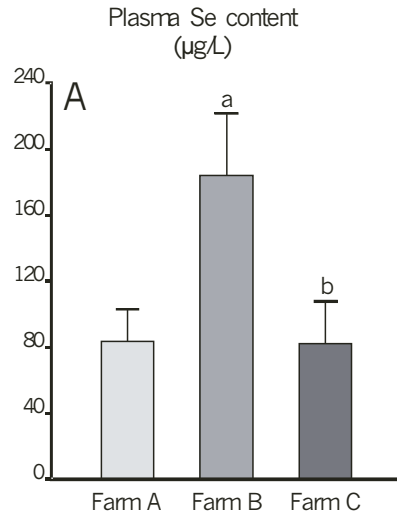

${ }^{a} p<0,01$ compared to Farm A $b_{p}<0,05$ compared to Farm B

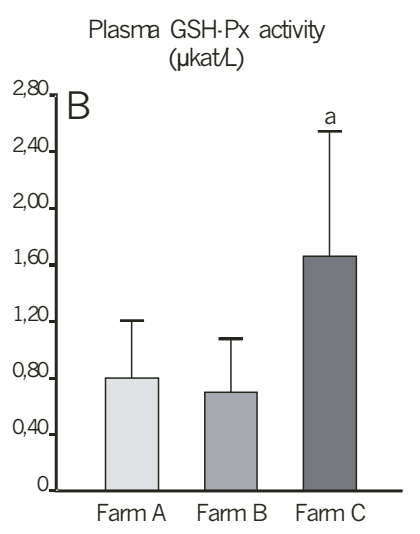

${ }^{a} p<0,05$ compared to Farms $A$ and $B$
Whole blood GSH-Px activity ( $\mu$ katL)

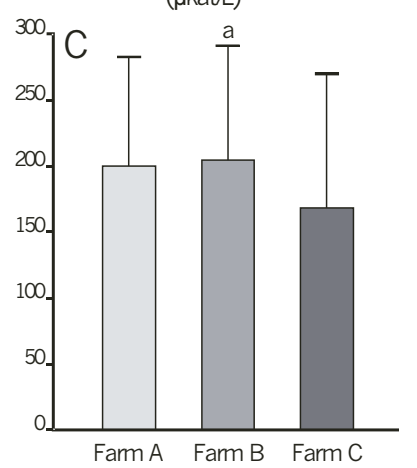

${ }^{a} p<0,05$ compared to Farm $A$

Figure 1. Selenium status of ewes from 3 farms in Vojvodina expressed as A) plasma selenium content; B) plasma glutathione peroxidase activity and C) whole blood glutathione peroxidase activity

The lowest mean blood plasma selenium concentration was in sheep from farm C (82.14 $\pm 25.09 \mu \mathrm{g} / \mathrm{L})$. A significantly higher selenium concentration was recorded in plasma samples from sheep on farm $B(183.90 \pm 37.10 \mu \mathrm{g} / \mathrm{L})$. 
Plasma GSH-Px activity was lowest at farm B $(0.70 \pm 0.37 \mu \mathrm{kat} / \mathrm{L})$. Significantly higher values were found in the sheep from farm C (1.66 \pm $0.88 \mu \mathrm{kat} / \mathrm{L})$.

Whole blood GSH-Px activity ranged from $194.38 \mu \mathrm{kat} / \mathrm{L}$ to $236.51 \mu \mathrm{kat} / \mathrm{L}$, the lowest being on farm $C(194.38 \pm 101.07 \mu \mathrm{kat} / \mathrm{L})$ and the highest on farm B (236.51 $\pm 85.72 \mu \mathrm{kat} / \mathrm{L})$.

Table 1. Selenium status of lambs in relation to their mothers (Farm A)

\begin{tabular}{|c|c|c|c|}
\hline & $\begin{array}{c}\text { Se content } \\
(\mu \mathrm{g} / \mathrm{L})\end{array}$ & $\begin{array}{c}\text { Plasma GSH-Px } \\
(\mu \mathrm{kat} / \mathrm{L})\end{array}$ & $\begin{array}{c}\text { Blood GSH-Px } \\
(\mu \mathrm{kat} / \mathrm{L})\end{array}$ \\
\hline \hline \multicolumn{4}{|c|}{ Lambs $(\mathrm{n}=10)$} \\
\hline \hline $\mathrm{M} \pm \mathrm{SD}$ & $50.78^{\mathrm{a}} \pm 10.06$ & $1.20 \pm 0.58$ & $424.21^{\mathrm{b}} \pm 117.19$ \\
\hline $\mathrm{SE}$ & 2.69 & 0.16 & 3.32 \\
\hline $\mathrm{CV} \%$ & 19.8 & 47.8 & 27.6 \\
\hline $\mathrm{IV}$ & $35.0-69.2$ & $0.51-2.12$ & $196.0-626.0$ \\
\hline \multicolumn{4}{|c|}{ Ewes $(\mathrm{n}=10)$} \\
\hline $\mathrm{M} \pm \mathrm{SD}$ & $83.44 \pm 19.09$ & $0.81 \pm 0.40$ & $199.50 \pm 83.24$ \\
\hline $\mathrm{SE}$ & 5.32 & 0.11 & 23.09 \\
\hline $\mathrm{CV} \%$ & 23.8 & 49.0 & 41.7 \\
\hline $\mathrm{IV}$ & $45.4-116.6$ & $0.40-1.92$ & $106.0-366.0$ \\
\hline
\end{tabular}

${ }^{a} p<0.05$ compared to ewes

b $p<0.01$ compared to ewes

The selenium content in the blood plasma of lambs $(50.58 \pm 10.06 \mu \mathrm{g} / \mathrm{L})$ was significantly lower in comparison to the respective values of their mothers (83.44 $\pm 19.09 \mu \mathrm{kat} / \mathrm{L})$. However, GSH-Px activities in the plasma and whole blood of lambs were consistently and significantly higher $(1.20 \pm 0.58 \mu \mathrm{kat} / \mathrm{L}$ and $424.21 \pm 117.19 \mu \mathrm{kat} / \mathrm{L}$ respectively).

\section{DISCUSSION}

Selenium concentrations in feedstuffs on the territories surrounding farm $A$ $(n=7)$, farm $B(n=10)$ and farm $C(n=4)$ were lower than $0.1 p p m$ in $>90 \%$ of the samples. Previous studies by Jovanovic et al. (1998) on 142 samples of feedstuffs from more than 30 locations throughout Vojvodina classified the region as marginally selenium deficient in accordance with the categorization given by Kubota et al. (1967).

Sheep feeding on farm B, which had the highest average selenium content $(>50 \mu \mathrm{gSe} / \mathrm{kg}$ ) in feedstuffs had a significantly higher plasma selenium content $(183.90 \pm 37.10 \mu \mathrm{g} / \mathrm{L})$ in comparison to those on farms $A$ and $C$. This indicates that plasma selenium concentration reflects the selenium concentration in 
feedstuffs (Braun et al., 1991; Stowe and Herdt, 1992). Data for plasma and serum selenium concentrations published in the literature are highly variable. Thus, Ullrey et al. (1978) found 25 - $53 \mu \mathrm{gSe} / \mathrm{L}$ (selenium deficient) in samples of sheep blood plasma from Michigan. Samples from North Dakota (Se adequate) contained 160-170 $\mu \mathrm{gSe} / \mathrm{L}$. Pamucku et al. (2001) detected an average plasma Se content of $303.65 \mu \mathrm{g} / \mathrm{L}$ in a flock of Akkaraman sheep in Turkey. After increased selenium intake, the rise of whole blood selenium level is slower than in plasma. This is because the majority of GSH-Px in whole blood is incorporated into erythrocytes at the time of erythropoiesis. Scholtz and Hutchinson (1979) established that in dairy cows $73 \%$ of whole blood selenium is present in the cellular blood components. Shepard and Miller (1981) showed that the activity of GSH-Px in sheep erythrocytes is 99 times higher than the activity in the blood plasma. Similar results were obtained by Peter (1980) who studied the activities of plasma and whole blood GSH-Px throughout the reproductive lifecycle of sheep. He found that after lambing the plasma GSH-Px activity was $0.63 \mu \mathrm{kat} / \mathrm{L}$ and whole blood GSH-Px activity was $301.0 \mu \mathrm{kat} / \mathrm{L}$. These results are close to the relationship obtained in our study (Figure 1).

Moreas (1986) stated that activities of whole blood GSH-PX in the range of $200-250 \mu \mathrm{kat} / \mathrm{L}$ can be considered to be adequate. This was confirmed by the results of Hudman et al. (1988) who showed that signs of selenium-responsive conditions could be expected at values below $165 \mu \mathrm{kat} / \mathrm{L}$. The values obtained during our research at farm A (199.50 $\pm 83.24 \mu \mathrm{kat} / \mathrm{L})$ and farm C (194.38 \pm $101.07 \mu \mathrm{kat} / \mathrm{L})$ are at the lower limit of the range determined by Moreas. The result obtained for farm B (236.51 $\pm 85.72 \mu \mathrm{kat} / \mathrm{L})$ is within the defined range of adequate selenium status. No clinical signs of selenium responsive diseases were diagnosed at the observed locations.

It is interesting to note that in regions marginally deficient in selenium, signs of ill-thriftiness and WMD in grazing animals are more frequently diagnosed in the dry period (Andres, 1999). Hence there is a need to study further seasonal variations in the Vojvodina region.

Our results for the selenium status of sheep and their lambs on farm A (Table 1) are in accordance with existing data on mother / offspring relationships. The lower mean plasma selenium content of lambs $(50.78 \mu \mathrm{g} / \mathrm{L})$ in comparison to their dams (83.44 $\mu \mathrm{g} / \mathrm{L})$ was similar to the relationship obtained by Hidiroglou (1980), who found a whole blood selenium concentration of $190 \mu \mathrm{g} / \mathrm{L}$ in pregnant sheep, while in newborn lambs the value was significantly lower $(140 \mu \mathrm{g} / \mathrm{L})$. Verlinden et al. (1983) established that the lower the selenium status of the mother, is the more efficient is the placental transfer of selenium to the fetus.

High plasma GSH-Px (1.20 $\mu \mathrm{kat} / \mathrm{L})$ and whole blood (424.21 $\mu \mathrm{kat} / \mathrm{L}) \mathrm{GSH}-\mathrm{Px}$ activities in suckling lambs can be explained by the heavy oxidative stress to which lambs are exposed at birth, thus creating a need for enhanced protection against peroxidation. It is no less important that newborns have a higher hemoglobin content and RBC count. Such differences have been established in other species as well. Thus Pavlata et al. (2003) confirmed that whole blood GSH- 
Px activity in calves is significantly higher (348.30 $\mu \mathrm{kat} / \mathrm{L})$ than that in cows (269.80 $\mu \mathrm{kat} / \mathrm{L})$.

\section{ACKNOWLEDGEMENT}

The present study was carried out with financial support from the Ministry of Science and Technology of the Republic of Serbia, Project No. 1881.

Address for correspondence:

Pešut Olivera

Faculty of Veterinary Medicine,

Bulevar JA 18, Belgrade

Serbia\&Montenegro

\section{REFERENCES}

1. Andres S, Mane MC, Sanches J, Barrera R, Jimenez A, 1999, Temporal variations in blood glutathione peroxidase (GSHPx) activity in sheep at pasture in a Mediterranean area, Vet J, 157, 186-8.

2. Andrews ED, Hartley WJ, Grant AB, 1968, Selenium-responsive diseases of animals in New Zealand, NZ Vet J,16, 433 .

3. Braun UR, Furer WF, Lutz H, 1991, Selenium and vitamin E in blood sera of cows from farms with increased incidence of disease, Vet Rec, 128, 5-13.

4. Erskine JR, Eberhart RJ, Hutchinson LJ, Scholz RW, 1987, Blood selenium concentrations and glutathione peroxidase activities in dairy herds with high and low cell counts, J Am Vet Med Ass, 190, 1417-21.

5. Günzler WA, Kremers H, Flòhe L, 1974, An improved coupled test procedure for glutathione peroxidase in blood, Klin Chem Klin Biochem, 12, 444 - 8.

6. Harpin I, Bauer L, Bedrica L, Potocnjak D, 2000, Correlation between glutathione peroxidase activity and the quantity of selenium in the whole blood of beef cows, Acta Vet Brno, 69, 87- 92.

7. Hidiroglou M, 1980, Trace Elements in the Fetal and Neonate Ruminant: A Review, Can Vet J, 21, 328-35.

8. Hoshino Y, Shigeru I, Osame S, Tagahashi E, 1989, Studies of serum tocopherol, selenium levels and blood glutathione peroxidase activities in calves with White Muscle Disease, Jpn J Vet Sci, 51, 741-8.

9. Hudman Jf, Costa ND, Robinson WF, 1988, An apparent phosphate selenium interaction in weaner sheep, $J$ Trace Elem electrolytes Health dis, 2, 105-12.

10. Jovanović IB, Pešut O, Mihailović M, Kosanović M, 1998, Selenium content in feedstuffs from Vojvodina (Serbia), Acta Veterinaria, 48, 5-6, 339-44.

11. Kubota J, Allaway WH, Carter DL, Cary EE, Lazar VA, 1967, Selenium in crops in the United States in relation to selenium-responsive diseases in animals, J Agr Food Chem, 15, 3, 448-53.

12. Moreas S, 1986, Untersuchungen au Abhangiigegkeit der Zink-, Mangan-, und Selengehalte in Lebern von Rindren aus ausgewahlten regionen Brasiliens, Inaugural-Disertation, Tierarztliche Hochschule, Hannover.

13. Osame S, Ohtani T, Itchio S, 1990, Studies on serum tocopherol and selenium levels and blood glutathione peroxidase activities in lambs with White Muscle Disease, Jpn J Vet Sci, 52, 705-10.

14. Pamucku T, Sel T, Yarim G, 2001, Blood serum concentrations of selenium and glutathione peroxidase activity in Akkaraman sheep, Turk J Vet Anim Sci, 25, 731-4.

15. Pavlata L, Prasek J, Podhorsky A, Pechova A, Haloun T, 2003, Selenium metabolism in cattle: maternal transfer of selenium to newborn calves at different selenium concentrations in dams, Acta Vet Brno, 72, 639-46.

16. Peter DW, 1980 , Selenium supplementation of grazing sheep. II. Response in plasma and erythrocyte activities of lambs and adult wethers, Aust J Agric Res, 31, 1005-17. 
17. Rotruck JT, Pope AL, Ganther HE, Swanson AB, Hafeman DG, Hoekstra WG, 1973, Selenium, biochemical role as a component of glutathione peroxidase, Science, 179, 588-90.

18. Sankari S, 1985, Plasma glutathione peroxidase and tissue selenium response to selenium supplementation in swine, Acta Vet Scand Suppl, 81, 1-127.

19. Scholz RW, Hutchinson LJ, 1979, Distribution of glutathione peroxidase activity and selenium in the blood of dairy cows, Am $J$ Vet Res, 40, 2, 245-50.

20. Shepard AD, Miller KR, 1981, Stability of GSH-Px in ovine blood samples under various storage conditions and response of this enzyme to different methods of selenium supplementation, $N Z$ Vet $J, 29,77$.

21. Stowe HD, Herdt TH, 1992, Clinical assessment of selenium status of livestock, J Anim Sci,70, 392833.

22. Ullrey DE, Light MR, Brady PS, Whetter PA, Tilton JE, Hanneman HA, Magee WT, 1978, Selenium supplements in salt for sheep, J Anim Sci, 46, 1515.

23. Verlinden M, Van Sprundel M, van der Auwera JC, Eylenbosh WJ, 1983, The selenium status of Belgian population groups, II Newborns, children and the aged, Biol Trace Elem Res, 5, 103.

24. Welby, $B$, Wolynetz MS, Verlingen $M$, 1987, Interlaboratory trial on the determination of selenium in lyophilized human serum, blood and urine using hydride generation atomic absorption spectrometry, Appl Chem, 59, 7, 927-36.

\title{
STATUS SELENA OVACA I NJIHOVE JAGNJADI U VOJVODINI
}

\author{
PEŠUT OLIVERA, JOVANOVIĆ IB, GVOZDIĆ D i STOJIĆ V
}

\section{SADRŽAJ}

Cilj ovog rada je bio da se odredi status selena ovaca i jagnjadi sa područja Vojvodine koja su marginalno deficitarna ovim mikroelementom. Koncentracija selena u hranivima dobijenim sa područja oko farmi A (Kać), B (Ečka) i C (Čoka) bila je niža od 0.1 ppm u više od $90 \%$ uzoraka. Koncentracija selena u plazmi ovaca sa ispitivanih farmi iznosila je $83.44 \pm 19.09 \mu \mathrm{g} / \mathrm{L}$ (farma A); $183.90 \pm$ $37.10 \mu \mathrm{g} / \mathrm{L}$ (farma B) i $82.14 \pm 25.09 \mu \mathrm{g} / \mathrm{L}$ (farma C). Aktivnost enzima glutation peroksidaze (GSH-Px) u plazmi bila je najniža na farmi $B(0.70 \pm 0.37 \mu \mathrm{kat} / \mathrm{L})$, nešto viša na farmi $A(0.81 \pm 0.40 \mu \mathrm{kat} / L)$ i statistički značajno viša na farmi $C$ (1.66 $\pm 0.88 \mu \mathrm{kat} / \mathrm{L})$. Aktivnost GSH-Px u punoj krvi ovaca kretala se u intervalu od $194.38 \mu \mathrm{kat} / \mathrm{L}$ (farma C) do $236.51 \mu \mathrm{kat} / \mathrm{L}$ (farma B).

$\mathrm{Na}$ lokalitetu Kać (farma A) ispitivan je status selena jagnjadi na sisi. Koncentracija selena u plazmi jagnjadi sa ispitivane farme iznosila je $50.78 \pm$ $10.06 \mu \mathrm{g} / \mathrm{L}$. Aktivnosti GSH-Px u plazmi (1,20 $\pm 0.58 \mu \mathrm{kat} / \mathrm{L})$ i punoj krvi jagnjadi $(424,21 \pm 117,19 \mu \mathrm{kat} / \mathrm{L})$ bile su značajno više u odnosu na vrednosti kod odraslih ovaca sa istog lokaliteta. 